\title{
Pursuing Sustainable Development Goals in Uganda: Do anti-corruption strategies of Management Development Institutes matter?
}

\author{
Christopher S. Mayanja* and James L. Nkata \\ Education Leadership and Management Department Uganda Management Institute, Kampala, Uganda.
}

Received 7 October, 2019; Accepted 25 November, 2019

\begin{abstract}
Sustainable development refers to using resources sparingly so that future generations may also use them for development. Sustainable Development Goals (SDGs) are a global development agenda adopted in 2015 to "end poverty, protect the planet, and ensure prosperity for all". The 15-year development agenda recognizes eradication of poverty in all its forms and dimensions, including extreme poverty, as the greatest global challenge and an indispensable requirement for sustainable development. However, many countries have not effectively implemented the global agenda, with one of the impediments being corruption especially in the public sector. The Maendeleo Policy Forum of 2017 in Addis Ababa, Ethiopia observed that corruption is a cross-cutting issue, which they agreed to combat. In fact, Africa is not short of normative tools to eradicate corruption. Nevertheless, corruption seems to be on the increase, eating up available resources for development, for improving lives and well-being of majority of Africans (HLPF, 2017). Uganda's Anti-Corruption Act of 2009 provides for the effectual prevention of corruption in both the public and the private sector with minimal success. Management Development Institutes have a key role to play if corruption in Uganda is to be combated. The paper therefore identified constraints towards implementation of anti-corruption strategies, as well as SDGs in Uganda. It also describes the role of Uganda Management Institute towards implementation of anti-corruption strategies in Uganda. It suggests recommendations towards engaging the higher educational sector in the campaign towards eradicating corruption, which would lead to effective implementation of SDGs.
\end{abstract}

Key words: Anti-corruption, sustainable development goals, Management Development Institutes, higher educational sector.

\section{INTRODUCTION}

According to Redclift and Woodgate (2013), sustainable development refers to utilization and exploitation of the resources in our midst today sparingly so that they are available to be used by future generations. Sustainable
Development Goals (SDGs) are a global development agenda that was adopted in September 2015. The 2030 Agenda builds on earlier commitments, more recently the aspirations set out in the Millennium Development Goals

*Corresponding author. E-mail: chrismayanja@gmail.com. 


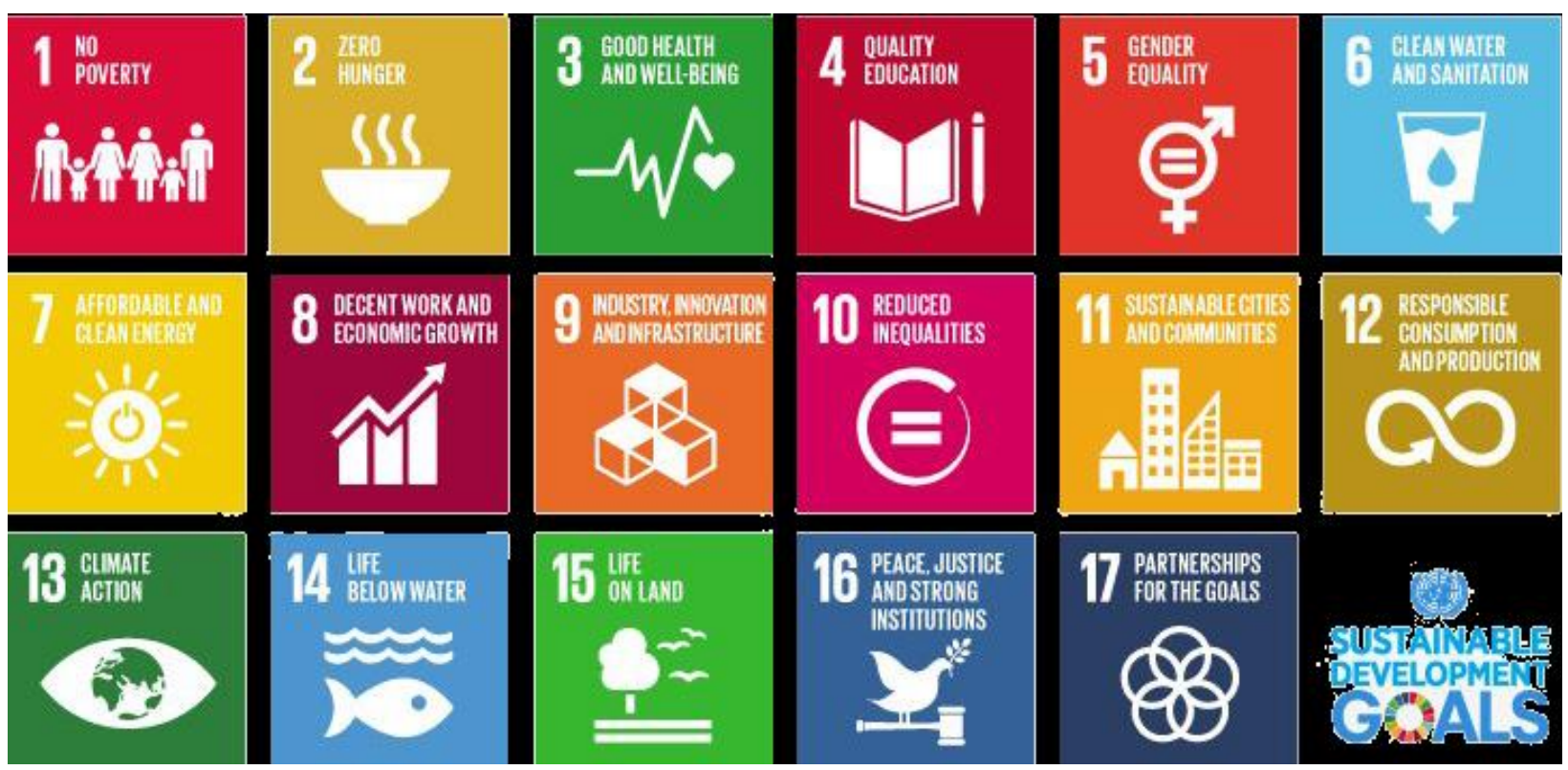

Figure 1. United Nations Sustainable Development Goals (UN Website).

(MDGs) and Millennium Declaration (UNRIS, 2017). These goals line out different policies towards community development including focusing on processes and means, rather than ultimate outcomes; and also taking care of the inter-linkages among the SDGs (OECD, 2015). This means that no single SDG would be achieved in isolation of all SDGs. They are in several instances linked to each other. Figure 1 shows the 17 SDGs.

The SDGs seek to "end poverty, protect the planet, and ensure prosperity for all". The 15-year development agenda recognizes eradication of poverty in all its forms and dimensions, including extreme poverty, as the greatest global challenge and an indispensable requirement for sustainable development. However, many countries have not effectively implemented the global agenda, with one of the impediments being corruption especially in the public sector.

The Maendeleo Policy Forum held on 7 February 2017 at UNDP Regional Service Centre for Africa, Addis Ababa, Ethiopia observed in an analysis of 17 African Peer Review member states that corruption is a crosscutting issue. All member states of the AU are signatories to the United Nations Anti-Corruption Convention (UNCAC). In addition, the AU established the Advisory Board on Corruption. The Regional Economic Communities (RECs) equally have normative instruments for combating corruption. In fact, Africa is not short of normative tools to eradicate corruption. Nevertheless, corruption seems to be on the increase, eating up available resources for development, for improving lives and well-being of majority of Africans (UNDP, 2017). Rose-Ackerman (2004) advances that countries with weak governance tend to register a lot of corruption which derails their development initiatives. Uganda's AntiCorruption Act of 2009 provides for the effectual prevention of corruption in both the public and the private sector. However, according to the First Annual Report on corruption in Uganda, Corruption remains an impediment to the development agenda and a barrier to poverty reduction, thus further impeding implementation of SDGs. The higher education sector in general and Management Development Institutes specifically, have a key role to play if corruption in Uganda is to be combated. The study therefore aims to find out how Management Development Institutes anti-corruption strategies facilitate pursuance of SDGs.

\section{METHODOLOGY}

The paper aimed at finding out how anti-corruption strategies of Management Development Institutes would facilitate pursuance of SDGs. The study deployed a qualitative approach, where unstructured interviews were held with key informants at Uganda Management Institute (UMI), the only public Management Development Institute in Uganda. UMI was selected because it holds the mandate of government to build capacity of public and private sector officials in the field of administration, leadership and management. These are the right targets to pursue SDG implementation and as such would benefit from curriculum on anti-corruption.

Interviews were conducted with the Chairperson of the Governing Council, Selected Council Members, the Three Directors, Deans of Schools, Consultants, Selected Academic and Non-Academic Heads of Department, and 
the Guild President. The selected interviewees were considered because they held information on business of Management Development Institutes while they could also ably articulate effect of corruption on pursuance of SDGs. Documents on the subject matter were reviewed in order to back up primary data generated from interviews. Content analysis was used to analyze the interview data in order to enable interpretation. This allowed analysis of the captured content and identifying the plots in arguments which connected presence of corruption as an impeding factor towards SDGs pursuance. Similarly, other arguments were registered in the affirmative that Management Development Institutes have a key role to play to curb corruption among public and private sector officials through their curriculum.

\section{IMPLEMENTATION OF SDGS}

SDGs were proposed at a convention were 193 countries participated in the year 2015, aimed at facing the future on review of the MDGs (UNDP, 2017; Voola, 2018; Mandela, 2015).

The 17 SDGs were localized by the participating countries through cascading strategies, adaptation of targets and indicators to inform the local context during prioritization (UN Women, 2017). Through localization, it is presumed that when nations are drawing their strategic plans, annual work plans and budget, they would integrate the SDGs so that their targets are actually implemented. Resources are expected to be allocated to SDG targets and as such during monitoring and evaluation of these plans, it would be evident that the SDGs are actually being implemented. Abebe, 2017).

Globally, several countries which are signatory to the 2030 sustainable development agenda have attempted to implement the SDGs. In order to ensure effective implementation of SDGs, they should be the subject of a lively, transparent, political debate in order to ensure and safeguard broad support for the goals (Lativia, 2018). Achievement of the SDGs definitely requires a lot of highest level support, as well as participation of key stakeholders in society depending on their strengths and interests. According to the Lativia (2018) report on implementation of SDGS, local governments are key participants since they are the closest public administration levels to the masses and thus, best able to involve relevant stakeholders and coordinate and direct local development in accordance with local priorities. Similarly, strategic management is crucial during the implementation of SDGs. According to the 2018 report on implementation of SDGs in Poland, if a country is to effectively implement all 17 SDGs, forward-looking planning would be necessary in order to address the needs of present and future generations and to bring on board new approaches to national strategic management (Poland, 2018).
Over the years, Uganda has had a great attempt to ensure implementation of SDGs through participating in several conventions and summits regionally and globally (Nakayima, 2016). This has been done through embarking on the implementation of the 2030 sustainable development agenda, a plan of action for people and the entire planet that prioritizes prosperity, peace and partnership in an inclusive manner (Uganda, 2016). Uganda has therefore integrated the priorities of the 2030 sustainable development agenda into the formulation of the National Development Plan (NDP) II, at a 76\% level as indicated by the United Nations Development Programme (Nakayima, 2016). According to the SDG Indicator Brief of 2015, Uganda has made tremendous improvement in some SDG indicators and focus areas, but a the performance leaves a lot to be desired if the country is to attain middle income status (PMA, 2015).

According to UNCTAD (2017), if the SDGs are to be achieved, there is need to deploy new innovative approaches that are socially inclusive and environmentally benevolent. This also amplifies the fact that implementation of SDGs is not an easy sail through; they may require a lot of focus and creativity to achieve. High Level Political Forum (Lativia, 2018) argues that developing economies lack sufficient commitment towards partnerships and cooperation as they lay strategies towards SDGs implementation. Partnerships and cooperation would go a long way to support implementation of SDGs since it would enable sharing of expertise and resources to enable successful delivery of public services and SDGs in general. Jaiyesimi (2016) also promotes that effective monitoring and evaluation systems would also facilitate effective implementation of SDGs.

Literature shows that developing economies have not performed well regarding implementation of SDGs. For instance Jaiyesimi (2016) asserts that this is partly due to over dependence donor funding unlike locally generated resources. It therefore becomes so hard for such countries to deliver on their respective goals and ambitions, which are generally cascading from the SDGs.

Jaiyesimi (2016) further argues that the private sector has a key role to compliment efforts by public sector during the implementation of SDGs. Relatedly, Gupta and Vegelin (2016) posit that more effort needs to be put on commitment by developing economies to ensure that SDGs have inclusive implementation where all stakeholders would be involved. Through the efforts of Public-Private Partnerships, the private sector may invest a lot of finances, experience and expertise into public service delivery. This will also play a contributory role towards successful implementation of SDGs since one of the impediments towards SDGs implementation has to do with insufficient resources and overreliance on donor funding. The following presents arguments on whether Management Development Institutes, through their mandate, can make a great contribution towards 
implementation of SDGs.

\section{ROLE OF MANAGEMENT DEVELOPMENT INSTITUTES IN IMPLEMENTATION OF SDGS}

Higher education institutions should, as they pursue their mandate, contribute towards the implementation of SDGs. Albareda-tiana et al. (2018) reiterate that at the UN General Assembly, a resolution that declared a Decade of Education for Sustainable Development (DESD) (2005-2014), invited all educational institutions to contribute to education for sustainability. According to Voola (2018), like universities, Management Development Institutes (MDIs) have a key role to play towards achievement of SDGs as follows:

(1) Provide knowledge, innovations and solutions to the SDGs;

(2) Create current and future SDG implementers;

(3) Demonstrate how to support, adopt and implement SDGs in governance, operations and culture; and

(4) Develop cross-sectoral leadership to guide the SDG response (Voola, 2018: 7).

Management Development Institutes usually admit students of working class caliber from the public, private and the third sector. Uganda Management Institute, like other Management Development Institutes, has a mandate to build capacity of managers in the public, private and NGO sector. Such skills and competences would contribute towards the achievement of the SDGs through integration of SDGs in strategic planning and management. On appreciation of the SDG indicators, managers would embark on their implementation, thus developing a cross-sectoral leadership to guide SDG response as promoted by Voola (2018). The argument presented by the scholar indicate that since Management Development Institutes focus on building management capacity among their students, they could make some contribution towards better execution of their roles back in their organizations.

Uganda Management Institute has a mandate to strengthen management capabilities of the country's public, private and civil society sectors, women and men alike, and contribute to organizational effectiveness (UMI, 2017). While pursuing its mandate, Uganda Management Institute strives to excel in developing practical and sustainable administration, leadership and management capacity. In the verge to undertake this mission, UMI supports the implementation of the SDGs through its programs as indicated by one of the study participants:

Through its programs -- most programs trace the extent to which they relate to particular SDGs. Facilitators endeavor to focus on SDGs implementation. Through research by both staff and participants; policy dialogues -
- SDG matters come up. At institutional level, UMI's vision, mission and objectives are framed towards contributing to SDGs implementation.

Tandon and Chakrabarti (2018) promotes that Higher Education Institutions play an important role in the achievement of the SDGs in society and community through ensuring that SDGs are included on local agendas; educate the SDG generation; build capacities for SDG policies, planning and management. This implies that while undertaking their mandate, Management Development Institutes should promote the SDGs agenda by introducing a curriculum that informs students on importance of implementing SDGs. Similarly, by taking advantage of the free platform to communicate to elites in society, MDIs need to sensitize their students on the agenda and also build their capacity in integrating SDGs in strategies, policies and plans. According to Voola (2018), since the SDG agenda covers a wide range of interconnected social, economic, and environmental challenges, the unique functions and expertise of higher education institutions may not easily be ignored if the SDGs are to be achieved. This, according to study participants implies that Uganda Management Institute and other Management Development Institutes are deemed to be at center stage in ensuring that SDGs are achieved by respective countries. One participant noted:

The various programs run by UMI target building capacity in administration, leadership and management. Such capacity would enable UMI graduates to apply the knowledge attained while guiding their respective organizations in the pursuance of their strategic direction. As you are aware, all organizations in the public, private and NGO sectors have a role to play in the pursuance of development - which is sustainable.

In specific terms, SDG 4 on quality education stipulates that the entire education sector should ensure quality deliverables. Voola (2018) promotes that SDGs recognize the importance of education to sustainable development through SDG 4, which calls for providing "inclusive and equitable quality education and promoting lifelong learning opportunities for all." The targets under this goal definitely call for the attention of higher education institutes to ensure that quality education is actually delivered. Similarly, Id et al. (2018) argue that to provide quality education is one of the most important missions of the United Nations. Thus, a lot of attention may have to be put on the goal, if other goals are to be achieved.

Management Development Institutes need to run curricula that drill students and participants into contributors towards effective implementation of SDGs. Jaiyesimi (2016) argues that in order to make effective contribution towards implementation of SDGs, it requires training and education in systems approaches to 
solutions, transdisciplinary initiatives, and co-design. While doing this, such graduates from Management Development Institutes should be multi-disciplinary and covering a wide scope of focus towards SDGs implementation. What is required is a new generation and category of sustainability professionals who can broker between global, national, and local issues, between research and use, and between biophysical and social aspects of sustainability; notably, this need is as acute in higher as in lower income countries (Jaiyesimi, 2016). The following presents arguments from the study on whether Management Development Institutes focus on integrating anti-corruption initiatives as they build capacity in management; they may eventually make a great contribution towards SDGs achievement. This is presumed to arise when the managers promote anticorruption tendencies in the work environment in order to better perform their functions.

\section{CORRUPTION: AN IMPEDING FACTOR TOWARDS SDGS' IMPLEMENTATION}

Mbaku (2015) and Englebert and Mbaku (2001) contend that the corruption vice has been around human life the world over since time memorial. This has led to two schools of thought; one that corruption enhances economic and social development, while the other argues that it impedes development. This study therefore aimed at finding out how corruption affects implementation of SDGs but also whether anti-corruption strategies of Management Development Institutes facilitate the relationship.

According to Kewaza (2016), corruption in Uganda has been at very high levels as the country was ranked at 139th out of 167 countries in the Corruption Perceptions Index as well as in the recent Africa edition of the Global Corruption Barometer. According to Kewaza (2016), corruption has led to pernicious effects stretching from substandard public service provision where there were reports of bribery during elections. Caravan (2014) reiterates that corruption is highly pronounced in Uganda giving an example from a study findings where government drugs are being sold expensively in private clinics! This deters pursuance of Goal 3 of the SDGs on good health and well-being of the people since it is just a few who can afford payment for the drugs. The arguments indicate that corruption greatly hinders successful achievement of goals and objectives, thus may also partly contribute towards non-achievement of SDGs.

Uganda's Anti-Corruption Act of 2009 provides for the effectual prevention of corruption in both the public and the private sector with minimal success (Uganda, 2009). However, according to the First Annual Report on corruption in Uganda, corruption remains an impediment to the development agenda and a barrier to poverty reduction (Uganda, 2011). Girling (1997) contends that it is very difficult to contain corruption as countries develop since development comes with real market situations involving financial gain on several parties. Globally, several other countries have also faced the same challenge where corruption is acknowledged to be part of social life (Poland, 2013; World Bank, 1998; Wilson, 2013). The argument promotes that within capitalist states like Uganda, Poland, USA and Lativia, corruption has over the years been a hitch to development. This confirms that corruption has over time impeded development efforts the world over and its regulation through the anti-corruption laws and campaigns have not been very effective. This gives meanings to the narratives of participants in this study who were in affirmative to the fact that corruption tendencies are such an impeding factor towards SDGs implementation. One participant indicated:

Corruption is a very impeding factor as far as implementation of SDGs is concerned. It manifests itself in many ways thus becoming a national concern; the reason why the President set up a number of agencies. $A$ lot of money is stolen from borrowed money, thus increasing the debt burden -- 'a double tragedy'. This undermines integrity of public systems -- donors hesitate to invest their money!

According to Amundsen (2006), corruption in Uganda is systemic and rather endemic implying that the vice is overly spread and rampant. With the indicated level of corruption, it makes the vice rather political and to a large extent bureaucratic. "Corruption affects all SDG related sectors, undermining development outcomes and severely compromising efforts to achieve health, education, gender equality, climate action, water and sanitation and other goals" (Guide, 2017). There have been attempts to combat corruption in Uganda where several agencies have been set up to undertake the uphill task.

Grochová and Otáhal (2012) and Mbaku (1992) advance that corruption probably crops from the desire of public officials to increase their levels of compensation. This is done through lobbying policy makers and politicians to support their activities which would rather increase their compensation through favours. Therefore, governments have over the years focused on putting across anti-corruption strategies so that development initiatives are not derailed. The government's strategies to fight corruption include the National Anti-Corruption Strategy (NACS), the Anti-Corruption Act, and the establishment of a specialized anti-corruption court within the judiciary. "Internationally, Uganda has been a signatory of the United Nations Convention against Corruption (UNCAC) as well as the African Union Convention on Preventing and Combating Corruption since 2004" (Kewaza, 2016). One participant in the study 
agreed that there were efforts in Uganda to combat corruption tendencies through several organs that were put up. The participant explained:

Organs like the Anti-corruption Unit in State House, the Health Monitoring Unit and others like the IGG, Auditor General's office, Parliament, Accountant General, and many others have attempted to lay strategies to combat corruption in Uganda.

The effort of such organs has not been in vain since several milestones towards combating the corruption vice have been met. The participant further observes:

Following Transparency International reports that Uganda had very high corruption tendencies; donors like GIZ, Democratic Governance Facility invest in anti-corruption tendencies affecting development. Agencies have achieved a lot; IGG reports cases of execution -newspapers. High profile executions for example in the pension case... have been pursued.

However, the fight against corruption has not been an easy sail through. Ittner (2009) advances that this fight is always constrained by a number of factors like spillover effects, vicious circles and adverse political incentives. This implies that though, the world over and in Uganda specifically, there have been efforts towards combating corruption in order to facilitate successful delivery of development, corruption tends to go to higher levels. It may imply that due to the players taking advantage of corrupt tendencies for self-interest the world over, it will remain a difficult vice to combat (Amundsen, 2006). The strategies laid to combat corruption may also be ineffective in one way or the other. Another participant in the study had reservations on effectiveness of strategies to combat corruption. He explained:

The so-called anti-corruption organizations have caused little or no change in the level of corruption. Indeed, they may have increased corruption by demonstrating that the corrupt have little to fear. For example, the golden handshake scandal revelations were followed by renewal of the contracts of some of the major culprits!

Though a lot of effort is seemingly put on anti-corruption strategies in Uganda, they still leave a lot to be desired. There is an argument that however much government has set up several structures to combat the corruption vice, some of them seem not to achieve the objective for which they were formed. A participant advances:

There are, in my opinion, no credible anti-corruption agencies. Government agencies, such as the IGG, do not impede corruption. They only provide cover to the political rulers and jobs to the ruling elite. NGOs are largely talking shops, which enrich their executives and are a pretext for international organs.

The arguments leave a lot to be desired since the corruption vice remains a very big impediment to implementation of SDGs. Not much may be achieved amidst such corruption tendencies yet still in some instances, the organs set up to combat the corruption vice, are entrapped in corruption tendencies themselves. One such incidence is when the Parliament of Uganda was petitioned to appoint a commission of inquiry into mass corruption in the judiciary. One retired Supreme Court Judge said:

There is evidence of inefficiency, incompetence, and corruption in the judiciary and unethical conduct by members of the bar (Parliament of Uganda, 2015).

This confirms the argument that the organs that are set up to reprimand the corrupt, are also massively infested by the corruption pandemic themselves, which makes it rather difficult to fight the vice. A participant in the study also had this to comments:

The biggest challenge towards strategies to combat corruption in Uganda is that the organs responsible are equally affected. For example, the IGG's office, the Police, Public Accounts Committee of Parliament; have on several occasions been involved in corrupt tendencies where during pursuance of culprits, you may never hear of some cases especially involving the 'big fish'; only to hear later that money exchanged hands and the case was abandoned! If therefore these organs meant to fight the corruption vice do not come clean of corruption themselves, then it will be very hard to solve the corruption pandemic.

Literature shows that there have been traces of corruption where people vying for elective positions in society dish out money in exchange for votes. Afrobarometer (2012), in a study about the 2011 elections in Uganda, $40 \%$ of participants indicated that they had actually been offered money or a gift in return for their votes. This has rather led to situations where if such people are elected into office, they would start by looking for money in the name of pay-back! This leads to substandard public services since funds intended to deliver them would on several occasions be diverted for personal gain. Scholars like Nwaodu et al. (2014) posit that though a lot of effort has put on curbing corruption, not much has been achieved, which further humpers development in Africa. This implies that there may be an issue of mind-set among the development players not only in Uganda, but the world over since even those that have the mandate to fight the vice, end up engaging in corrupt tendencies themselves. Study participants indicated that in several occasions, when corrupt officials are being executed, they are at times shielded by other 
influential officials of government. One participant in the study observed:

The corrupt are major funders of the political elite. Since, the political rulers are cushioned by the corrupt; they only pay lip service to fighting corruption. (Indeed, the corrupt that go to jail are those without political godfathers). Furthermore, the majority of the population is so poor and scared that it cannot remove the political rulers who are in bed with the corrupt.

\section{ROLE OF MANAGEMENT DEVELOPMENT INSTITUTES IN COMBATING CORRUPTION}

According to Mbaku (2000), corruption in Africa "is a direct consequence of poorly developed laws and institutions, and distorted incentive structures". Otáhal and Grochová (2012) also contend that corruption reduces efficiency of the rule of law and thus, impedes development. Meanings derived from the arguments are that corruption may be facilitated by the public officers themselves through taking advantage of the weak governance systems as advanced by several scholars (Nwaodu et al., 2014; Girling, 1997; Poland, 2013).

Since the targeted students in Management Development Institutes include public officials, they therefore have a key role to build capacity of public, private and NGO sector players in administration, leadership and management. This on several occasions is aimed at improved performance of organizations, which mainly pursue sustainable development. If sustainable development is to be achieved, corruption tendencies in the different sectors need to be done away with. Following from the mandate of Management Development Institutes, they definitely have a key role to play towards combating corruption. Uganda Management Institute's core mandate is to strengthen the management capabilities of the country's public, private and civil society sectors (UMI, 2017). UMI also makes a contribution towards combating corruption through laying several strategies including establishing an anticorruption center and developing an anti-corruption course. One study participant reiterated:

UMI policies like code of ethics and the security policy are aimed at combating corruption at the Institute. UMI has a plan to set up the 'Anti-corruption Academy' within the School of Civil Service, Public Administration and Governance, which will aim at delivering programs towards anti-corruption.

Management Development Institutes have a key role to play towards combating corruption through undertaking programs that have content on anti-corruption. Staff members may be encouraged to undertake research on anti-corruption and effect of corruption on development and thereafter share with different practitioners at policy dialogues or research seminars. Uganda Management Institute puts in concerted effort towards knowledge generation and dissemination on anti-corruption for sustainable development. Staff members prepare papers and disseminate them at various fora both locally and internationally. One study participant noted:

Several UMI staff participate in anti-corruption sessions for instance at the 2018 AAPAM conference held in Botswana, where anti-corruption was a sub-theme. A paper on corruption in public services was also presented at the African Public Service Day (An African Union recognized day). Other staff members have also presented papers on corruption at national and lower levels.

Management Development Institutes may also take up the corporate social responsibility to sensitize masses on anti-corruption and the effect of corruption tendencies on sustainable development. Among strategies that may be laid is holding talk-shows where staff members and students may be hosted to share generated knowledge about the effect of corruption on sustainable development. These may help public, private and NGO sector practitioners to appreciate that sustainable development may only be achieved if corruption tendencies are done away with. The talk-shows may also build awareness among the masses, who are the main beneficiaries from development initiatives about corruption and anticorruption strategies, as well as acting as whistle blowers in case of identifying corrupt officials for execution. One study participant promoted:

UMI may contribute towards the anti-corruption campaign through community engagement for instance holding talkshows where staff may participate.

Management Development Institutes need to serve as examples in the promotion of anti-corruption tendencies through their own processes. They need to follow the minimum standards and guidelines like declaration of income, assets and liabilities, names, incomes, assets and liabilities of his or her spouse, children and dependents, within three months after becoming a leader and thereafter every two years during the month of March (IGG, 2016). In this regard, one of the study respondents observed:

Adherence to national requirements for example declaration of assets every two years is aimed at reducing corruption tendencies among public officers.

Relatedly, Uganda Management Institute has been at the forefront of reducing corruption tendencies, where this is evident from the Institute's reputation regarding the vice. Another respondent observed: 
Corruption cases at the institute have all been cleared. UMI through its practices endeavors to minimize corruption tendencies through financial processes, noninterference from the top; participatory CouncilManagement relationship; and the decision making processes.

From the participant's views on the contribution of UMI towards combating corruption tendencies, I pick that Management Development Institutes need to start with themselves if they are to promote anti-corruption tendencies. One respondent noted:

Management Development Institutes should serve as examples in the fight against corruption tendencies.

This is basically through ensuring openness and transparency in all their transactions so that they may serve as role models due to being exemplary to other public, private and NGO entities.

Literature shows that the implementation modalities of SDGs lack interlinkages and interdependencies among goals, regardless of their ambition to be universal, indivisible, and interlinked (Jaiyesimi, 2016). This implies that without focus on alignment of countries' strategic directions to the SDGs, it becomes very difficult to actually implement them. The same challenge was also noted during the implementation of MDGs which preceded SDGs. Lack of clear guidance on policy changes or how the goals ought to be achieved were some of the often reported challenges to the implementation of MDGs (Jaiyesimi, 2016). Findings from both interview and document review reveal that corruption affects SDGs' implementation and thus may have to be focused on if they are to be achieved.

\section{Conclusion}

Following from the discussion of interview and document review findings, the study found out that implementation of SDGs in developing countries like Uganda has not met the expectation desired. This has mainly been attributed to lack of efficient and effective processes that support achievement of the SDGs. This is also being attributed to high corruption tendencies especially among key players in the public sector yet they are supposed to be the custodians of the implementation process.

Though implementing countries have made a strong attempt to implement the SDGs, there is still a lot to be desired. UNCTAD (2017) argues that for the less developed countries financial constraints affect the achievement of SDGs. Such countries are characterized by shortages of human capital and skills and by poor infrastructure, which may not easily allow achievement of the SDGs.

From this study, it was found out that lack of efficient and effective processes in developing countries has been a major impediment on the implementation of SDGs. Efficient processes may include close follow up of undertakings to ensure that there is no wastage of resources and thus delivery of the desired change (effectiveness) within the society. In conclusion therefore, the more emphasis that may be put on putting in place more efficient and effective processes, the higher the developing countries will register regarding SDGs' implementation.

The study found out that corruption tendencies are highly registered especially among developing countries. It further found out that in such countries, very low scores are registered regarding implementation of SDGs. The study also found out that corruption is a leading impeding factor on implementation of SDGs. It was therefore concluded that the more the emphasis put on laying anticorruption strategies, the higher the scores in SDGs' implementation.

In this study, it was found out that Management Development Institutes have a key role to play regarding laying strategies towards anti-corruption tendencies. In conclusion, therefore, the more the Management Development Institutes prioritize laying strategies and developing curricula that promotes anti-corruption tendencies, the more the vice will reduce. The study also found out that by laying such strategies on anticorruption, Management Development Institutes would be making a very high contribution towards implementation of SDGs. It was therefore concluded that if Management Development Institutes develop curricula which focus on promoting anti-corruption tendencies and SDGs' implementation, they will have a major contribution towards implementation of the SDGs.

The study found out that developing economies had a big challenge where their development strategies are not well linked to the SDG framework. It is therefore concluded that inter-linkages of development goals and country visions with the SDGs would allow ease of their implementation.

The study also found out that Public-Private Partnerships (PPPs) may go a long way in supporting SDGs implementation. They may also reduce corruption tendencies since the private sector would have a lot of control over their own resources, which are only recovered on successful execution of projects. In conclusion therefore, the more governments in developing economies utilize the PPPs approach, the more likely the success in the implementation of SDGs.

The study also found out that effective monitoring and evaluation of SDGs would allow their successful implementation. Governments should therefore ensure that all key stakeholders are involved in monitoring and evaluation processes, if SDGs are to be successfully pursued. According to UN Women (2017), political commitment should be at the highest level if SDGs are to be achieved. Close follow up on the SDGs' 
implementation as well as strategies to curd corruption tendencies may facilitate successful achievement of governments. In conclusion therefore, if developing economies prioritize the monitoring and evaluation function in their operations, through collection of performance data, its analysis, interpretation and reporting, then achievement of objectives will be ensured. This is due to the fact that with proper follow up on performance of SDGs, success would be easily appreciated and maintained, while constraints will also be appreciated and combated. This kind of arrangement will enable learning from performance and as such always maintaining performance on the right track.

\section{RECOMMENDATIONS}

The study recommends that governments in developing economies should put in place more efficient and effective process for the pursuance of SDGs implementation. This may be done through ensuring that the people assigned the responsibility to deliver on the SDGs are actually held accountable for their achievement or non-achievement whatever the case may be. Further to this strategy, Uganda needs to pursue policies that actually help the people other than those that would again promote corruption. Such policies may have to do with focus on improved household incomes and employment creation.

Developing countries like Uganda need to draw strategic plans which are well linked to the SDGs framework. They need to further cascade these strategies into sector strategic plans, downwards to the lowest levels. This will ease focus towards their implementation and thus better performance will be registered.

More effort should also be put on anti-corruption strategies, where the agencies assigned the role of combating corruption among developing economies are actually given due support to undertake their initiatives. Such strategies may include improvement of the public officers' remuneration, but also developing curricular which promotes anti-corruption especially in the higher education sector. More resources may be allocated towards such agencies since the study found out that their effort is actually evident, though they may still be facing several constraints, insufficient funding being one of them. Since participants in the study also revealed that corruption may be an issue of culture, the ministry in charge of ethics and integrity in Uganda may also be allocated more funding towards combating corruption.

Developing countries like Uganda need to prioritize infrastructural development since it is also argued that poor infrastructure impedes SDGs implementation. Infrastructure like improved road network, hospital buildings, classrooms and market structures may go a long way in successful implementation of SDGs.

Governments in the developing world, where Uganda fall need to utilize the Public-Private Partnerships approach for successful implementation of SDGs. Focus would be put on infrastructural development in public service provision like health, roads, education and agricultural sectors.

Developing economies like Uganda need to establish robust monitoring and evaluation systems from the national and sector level to the lowest levels of governance. This may be achieved through building capacity of the key stakeholders in the area of monitoring, evaluation and learning, as well as developing function monitoring and evaluation systems. This will go a long way into facilitating the implementation of SDGs.

Management Development Institutes like Uganda Management Institute need to re-design their Postgraduate, masters and PhD curricula to incorporate strategies of SDGs implementation as well as anticorruption strategies. Students and participants at these Institutions will gain knowledge and skill on the implementation of SDGs, as well as strategies to combat corruption. Mindset among these students and participants will also be changed towards anti-corruption tendencies, where satisfaction would be sought from successful implementation of SDGs.

Management Development Institutes, in their corporate social responsibility may also promote implementation of SDGs as well as campaign for combating corruption tendencies. This may be achieved by organizing talk shows, mobilization of communities and public servants and utilizing other modes of Information, Education and Communication (IEC). These institutions may ride on ability to easily organize numbers of people through their capacity building initiatives and from within their classrooms.

\section{REFERENCES}

Abebe JO (2017). Accelerating the Implementation of Agenda 2030 on Sustainable Development-Approaches by African Countries in the Localization and Implementation of Agenda 2030 on Sustainable Development, (December). UN Women DOI: 10.13140/RG.2.2.20139.75045

Albareda-tiana S, Vidal-raméntol S, Fernández-morilla M (2018). Implementing the sustainable development goals at University level International Journal of Sustainability in Higher Education Article information:, (March). https://doi.org/10.1108/IJSHE-05-2017-0069

Amundsen I (2006). Political corruption: An Introduction to Issues. URL: https://www.cmi.no/ publications/file/1040-political-corruption.pdf

Caravan (2014). Corruption and the Service Delivery Tragedy in Uganda, (September), 1-44. Retrieved from https://uganda.actionaid.org/sites/uganda/files/anticorruption_report.pdf

Englebert P, Mbaku JM (2001). Corruption Cleanups in Africa Lessons from Public Choice Theory, (January). https://doi.org/10.2307/3097546

Girling J (1997). Corruption, Capitalism and Democracy. Routledge Studies in Social and Political Thought. URL: http://www.untagsmd.ac.id/files/Perpustakaan_Digital_1/ CORRUPTION\%20Corruption,\%20Capitalism\%20and\%20Democra cy.pdf

Grochová L, Otáhal T (2012). Corruption, Rule of Law, and Economic Efficiency: Virginia vs. Chicago Public Choice Theories. veřejné volby, 6. URL: https://is.vsfs.cz/repo/4811/Grochova_Otahal.pdf 
Gupta J, Vegelin C (2016). Sustainable development goals and inclusive development. International Environmental Agreements: Politics, Law and Economics. https://doi.org/10.1007/s10784-0169323-z

IGG (2016). Inspectorate of Government Online Declaration System (IG-ODS) User Manual. URL: https://igdeclarations.igg.go.ug:8180/static/declarations/docs/IG_ODS _User_Manual.pdf

Id SA, Hussain T, Li B (2018). The Implementation of Sustainable Development Goals in "BRICS" Countries. https://doi.org/10.3390/su10072513

Ittner S (2009). Fighting Corruption in Africa - A Comparative Study of Uganda and Botswana Dissertation. URL: https://www.unispeyer.de/files/de/Forschung/Publikationen/Dissertationen/ IttnerStefan.pdf

Jaiyesimi R (2016). The Challenge of Implementing the Sustainable Development Goals in Africa: The Way Forward, (2016), 13-18. URL: http://www.bioline.org.br/pdf?rh16029

Kewaza M (2016). Fighting corruption in Uganda: Despite small gains, citizens pessimistic about their role. Afro Barometer (77), 1-12. URL: http://afrobarometer.org/sites/

default/files/publications/Dispatches/ab_r6_dispatchno77_uganda_co rruption.pdf

Lativia (2018). Implementation of the Sustainable Development Goals. Report to the UN High Level Political Forum on Sustainable Development 2018. URL: http://sdgtoolkit.org/wpcontent/uploads/2018/10/VNR_Latvia_Implementation_of_the_SDGs. pdf

Mbaku JM (1992). Bureaucratic Corruption in Africa: The Futility of Cleanups, 16(1). URL: http://dlc.dlib.indiana.edu/dlc/bitstream/handle/10535/3186/Vol.pdf

Mbaku JM (2000). Controlling Corruption in Africa: a Public Choice Perspective. In: Hope K.R., Chikulo B.C. (eds) Corruption and Development in Africa. Palgrave Macmillan, London. https://doi.org/10.1057/9780333982440_7

Mbaku JM (2015). Corruption Cleanups in Africa Lessons from Public Choice Theory, (August 2008). https://doi.org/10.1177/0021909608091975

Nakayima E (2016.). Achieving the SDGs: Fundamentals for Uganda. URL: http://ngoforum. or.ug/wpcontent/uploads/downloads/2016/06/Achieving-the-SDGs-EN.pdf

Nwaodu N, Adam D, Okerere O (2014). A Review of Anti-corruption Wars in Nigeria. Africa's Public Service Delivery and Performance Review. Doi: 10.41021apsdpr.v2i3.63

PMA (2015). SDG Indicator Brief. Performance Monitoring and accountability $2020 \quad$ Report, $1-4 . \quad$ URL: https://www.pma2020.org/reports/pma2015uganda-sdg-indicatorbrief

Poland (2018). Implementation of the Sustainable Development Goals in Uoland. URL: https:// sustainabledevelopment.un.org/content/documents/19409Poland_VN R_20180615.pdf

Poland (2013). Anticipated Corruption Threats in Poland. Central Anticorruption Bureau. https://cba.gov.pl/ftp/publikacje/ANTICIPATED_CORRUPTION_THR EATS_IN_POLAND.pdf

Rose-ackerman S (2004). The Challenge of Poor Governance and Corruption. https://www.researchgate.net/publication/239756819_The_Challenge _of_Poor_Governance_and_Corruption

Redclift M, Woodgate G (2013). Sustainable Development and Nature: The Social and The Material. URL: https://www.researchgate.net/publication/264413069_Sustainable_D evelopment_and_Nature_The_Social_and_The_Material

Uganda (2016). Review Report on Uganda's Readiness for Implementation of the 2030 Agenda. MOFPED. URL: https://sustainabledevelopment.un.org/content/documents/10689Uga nda \%20Review\%20Report_CDs1.pdf
OECD (2015). Policy Coherence for Sustainable Development in the SDG Framework Shaping Targets and Monitoring Progress, 1-12. URL:

http://www.oecd.org/governance/pcsd/Note\%20on\%20Shaping\%20T argets.pdf

Tandon R, Chakrabarti K (2018). Partnering with Higher Education Institutions for SDG 17: The Role of Hiher Education Institutions in Multi-Stakeholder Partnerships. URL: https://www.pria.org/uploaded_files/writing_pdf/1527828593_Higher $\% 20$ education-occasional\%20paper-Final.pdf

Uganda (2011). Second Annual Report on Corruption in Uganda Using the Data Tracking Mechanism. Inspectorate of Government. URL: https://www.igg.go.ug/static/files/publications/ig-report-corruption.pdf

Uganda (2009). The Anti Corruption Act. URL: https://ulii.org/system/files/legislation/act/2009/ 2009/the_anti_corruption_act_no_6_of_2009_pdf_77364.pdf

Uganda Management Institute (UMI) (2017). Uganda Management Institute 2017-2020 Aligned Strategic Plan.

UNCTAD (2017). New Innovation Approaches to Support the Implementation of Sustainable Development Goals. URL: unctad.org/en/PublicationsLibrary/dtlstict2017d4_en.pdf

UNDP (2017). Corruption, an Impediment Factor to SDGs Achievement: What Must Africa Do? Report of the Maendeleo Policy Forum, Addis Ababa, Ethiopia. URL: https://www.undp.org/content/dam/rba/docs/undp_rba_7th\%20Mande leo\%20Policy\%20F

UNRIS (2017). Challenges and Opportunities in the Implementation of the Sustainable Development Goals. retrieved from: https://www.undp.org/content/dam/undp/library/SDGs/ English/Global\%20Trends_UNDP\%20and\%20UNRISD_FINAL.pdf

Voola R (2018). Getting Started With SDGs in Universities. URL: http://ap-unsdsn.org/wp-content/uploads/University-SDGGuide_web.pdf

Wilson AJ (2013). Comparative Political Corruption in the United States: The Florida Perspective. Graduate Theses and Dissertations. URL: http://scholarcommons.usf.edu/etd/4613

World Bank (1998). Corruption in Lativia: Survey Evidence. URL: http://www1.worldbank.org/ publicsector/Latviasurveyreport.pdf 